\title{
ネパールにおけるモンスーン季の降水の地域特性
}

\author{
前野加代理* 大森 博 雄* 松 本 淳** \\ 林泰 一***
}

\section{Characteristics of Daily Precipitation during the Monsoon Season in Nepal}

Kayori MAENO *, Hiroo OHMORI *, Jun MATSUMOTO ** and Taiichi HAYASHI ***

\begin{abstract}
This paper analyzes the characteristics of daily precipitation during the monsoon season from June to September for 21 years from 1976 to 1996 in Nepal, which is situated in the southern Himalaya. The average monsoon precipitation, and the number of rainy days in Nepal are 1,410 $\mathrm{mm}$, and 73 days, respectively. On the basis of the total monsoon precipitation and the number of rainy days, 1978, 1984, and 1985 are classified as wet years, and 1977, 1979, and 1992 are classified as dry years. Nepal is divided into six regions on the basis of the statistical characteristics of total monsoon precipitation and number of rainy days.

On the other hand, the distribution pattern of 5-year probable rainfall in Nepal, is considerably different from that of average monsoon precipitation. Five-year probable rainfall is small in northern Nepal, and becomes large toward the south. On the basis of 5-year probable rainfall, which is regarded to be the threshold value of heavy rainfall in Nepal, heavy rainfall occurred more frequently in 1981 and 1987. These years did not agree with the wet years based on total precipitation and number of rainy days, indicating that the occurrence of heavy rainfall that causes water hazards in Nepal does not synchronize with wet years.
\end{abstract}

Key words : Nepal, monsoon, daily precipitation, probable rainfall amount キーワード : ネパール, モンスーン, 日降水量, 確率雨量

\section{I.はじめに}

世界の屋根，ヒマラヤの中核にあるネパールは， 北を中国 (チベット)，南と東西をインドに囲まれ た内陸の山岳国家で, 北緯 26 度 15 分〜 30 度 30
分, 東経 80 度 15 分〜 88 度 15 分に位置する東西 約 $890 \mathrm{~km}$, 南北約 $190 \mathrm{~km}$, 面積約 15 万 $\mathrm{km}^{2}$ の ほぼ長方形の形をした国である（図 1)。ネパール の地形は主に, 南部のインド平原に続くタライ (Terai) 平原, 中間の山間部, 北部の山岳部（ヒ

\footnotetext{
* 東京大学大学院新領域創成科学研究科環境学専攻

**東京大学大学院理学系研究科地球惑星科学専攻

$* * *$ 京都大学防災研究所

* Department of Natural Environmental Studies, Institute of Environmental Studies, Graduate School of Frontier Sciences, University of Tokyo

** Department of Earth and Planetary Science, Graduate School of Science, University of Tokyo

*** Disaster Prevention Research Institute, Kyoto University
} 


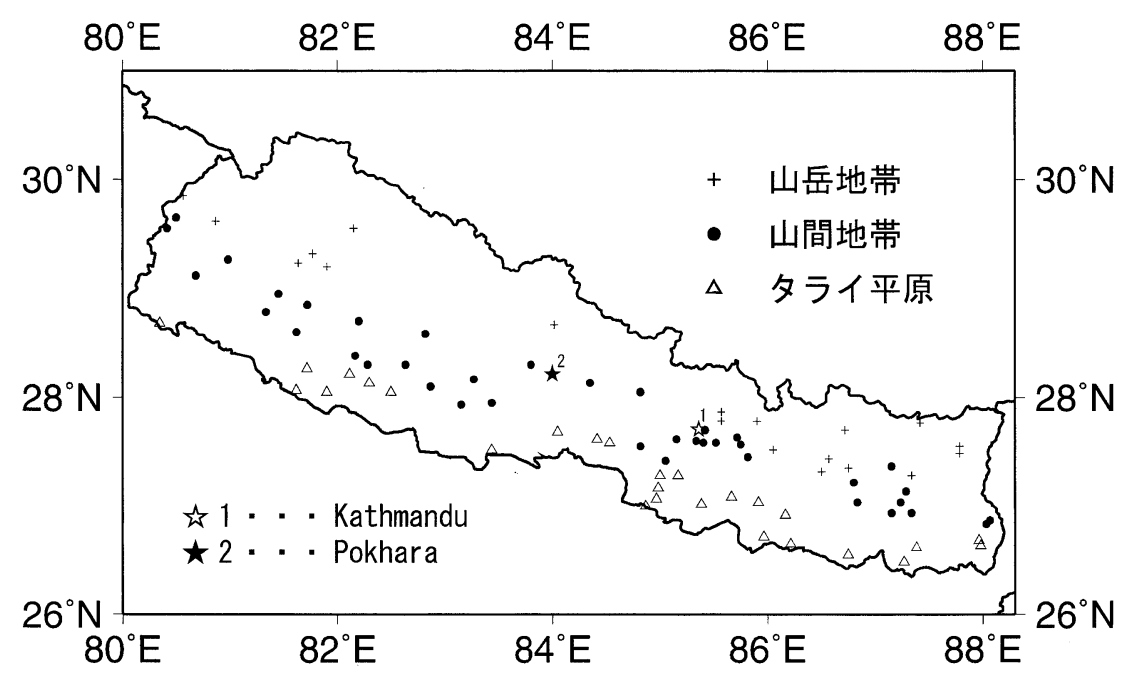

図 1 データを使用した雨量観測地点の分布.

Fig. 1 Distribution of meteorological stations used in this study.

マラヤ）に分けられる。標高差は，世界最高峰の エベレスト $(8,848 \mathrm{~m})$ からタライ平原の標高 $100 \mathrm{~m}$ 弱までと, 8,700 $\mathrm{m}$ 以上を示す。ネパール では北部ヒマラヤ地域の山岳寒冷地域から南部夕 ライ平原の亜熱帯地域まで, 様々な気候帯が標高 に応じて分布している。その大部分は带熱帯モン スーン気候下にあり，6〜9月までの雨季と 10〜 5 月までの乾季に分かれる。この雨季に年降水量の 約 $80 \%$ が集中し, 最も雨量が多いのは 7 月, 最 も乾燥するのは 12 月である。ネパールでは科学 技術省の水文気象局 (Department of Hydrology and Meteorology: DHM) が 20 世紀中頃から気 象観測を行っている。しかしネパールの降水量に 関して日本で一般に入手できる研究は, 山田 （1971）など月降水量を用いた報告があるものの, 日降水量を用いた研究は Yasunari (1976) や安 成・藤井（1983）を除けばほとんど見当たらず, これらの研究で扱っている年代も古い。そこで本 研究ではネパールにおける 1976〜 1996年の日降 水量デー夕を用いて, モンスーン季の降水量につ いて解析した。まず，ネパールの平均モンスーン 降水量・雨日数を調べ, ネパールの地域区分を試 みた。次に, 観測地点ごとに, 日降水量の再現期
間と確率雨量を算出することによって降水量の年 変動を解析した。

\section{II. 使用するデータ}

本研究では, ネパール科学技術省水文気象局に よる日降水量の観測值 $(0.1 \mathrm{~mm}$ 単位 $)$ を使用し た ${ }^{1)}$ 。対象期間は $1976 \sim 1996$ 年 (21 年間) のモ ンスーン季 $(6 \sim 9$ 月, 年 122 日, 計 2,562 日間 $)$ である。日単位での変動を詳しくみていくために 1976 年以降のデータに欠測がない雨量観測地点 （全部で 87 地点, 図 1) を選び出した。

\section{III. 結 果}

\section{1）ネパールの雨季}

ネパールの降水は主に夏のモンスーンによって もたらされる。インド・ヒマラヤ地域では, 夏季 に南半球から赤道を越えて吹く南西モンスーンが アラビア海やベンガル湾で水蒸気の補給を受け, 北部インドにある南アジア低気圧に向かって南よ りの風となってヒマラヤ地域へ入ってくる。この 湿った空気が流入することで，ヒマラヤ地域に雨 が降る。なお，モンスーンに伴う雨季は南から北 上してくる。ネパールの首都カトマンズ（図 1 の 


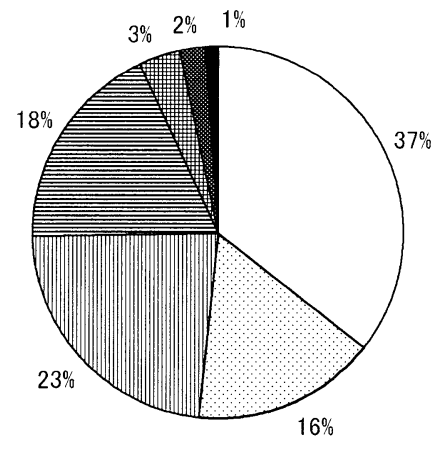

$\square 0 \sim 500 \mathrm{~m}$

$\square 500 \sim 1000 \mathrm{~m}$

四1000 1500m

目 $1500 \sim 2000 \mathrm{~m}$

因 $2000 \sim 2500 \mathrm{~m}$

$2500 \sim 3000 \mathrm{~m}$

- $3000 \sim 3500 \mathrm{~m}$
図 2 使用した雨量観測地点の標高割合.

Fig. 2 Percentage of meteorological stations used in the present study by elevation zone above sea level in Nepal.
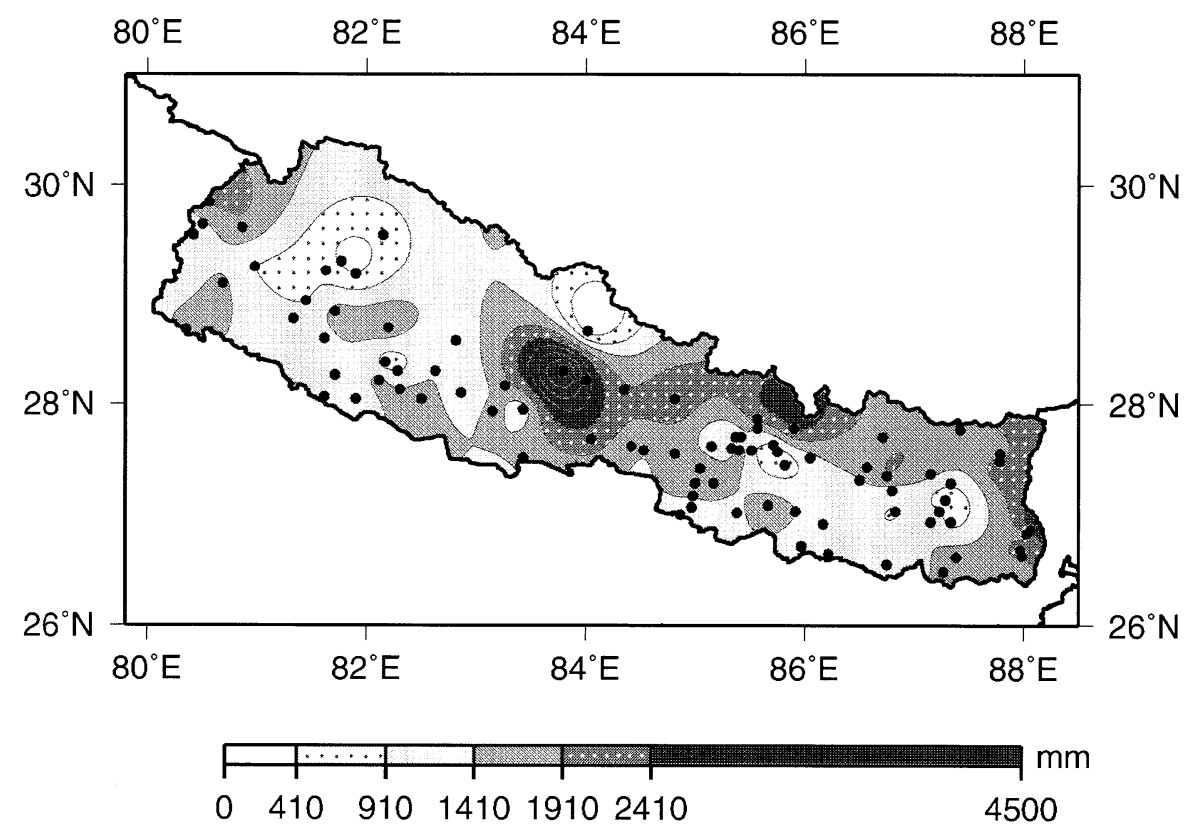

図 3 モンスーン平均降水量.

降水量の階級区分は, 平均值 $1,410 \mathrm{~mm}$ を中心に, 上下 $500 \mathrm{~mm}$ とし, 降水量の多い地域 · 少ない地域を示した。黒丸は使用した雨量観測地点.

Fig. 3 Distribution of average monsoon rainfall in the period from June to September. To classify the regions into heavy rainfall areas and/or light rainfall areas, rainfall amounts are classified at intervals of $500 \mathrm{~mm}$ from the average value of $1,410 \mathrm{~mm}$ in Nepal. Solid circles are the meteorological stations used in the present study.

々1)でのモンスーン入りは平均 6 月 12 日，モン スーン明けは 9 月 21 日である (Nayava, 1980)。 それゆえ，前記のように $6 \sim 9$ 月の降水を解析対 象とした。

本研究で使用した観測地点の標高は, 最低が $72 \mathrm{~m}$, 最高は $3,420 \mathrm{~m}$ で, 観測地点の約 $50 \%$ は
1,000 m 以下となる（図 2)。西部での地点密度は 低く（図 1)，また北部山岳地帯では谷の集落で観 測されているため，ネパールにおける降水の全体 像をつかむには限られたデー夕からの推測になる。 本研究で使用したネパール 87 地点の 21 年間の平 均モンスーン降水量（モンスーン季の合計降水量 


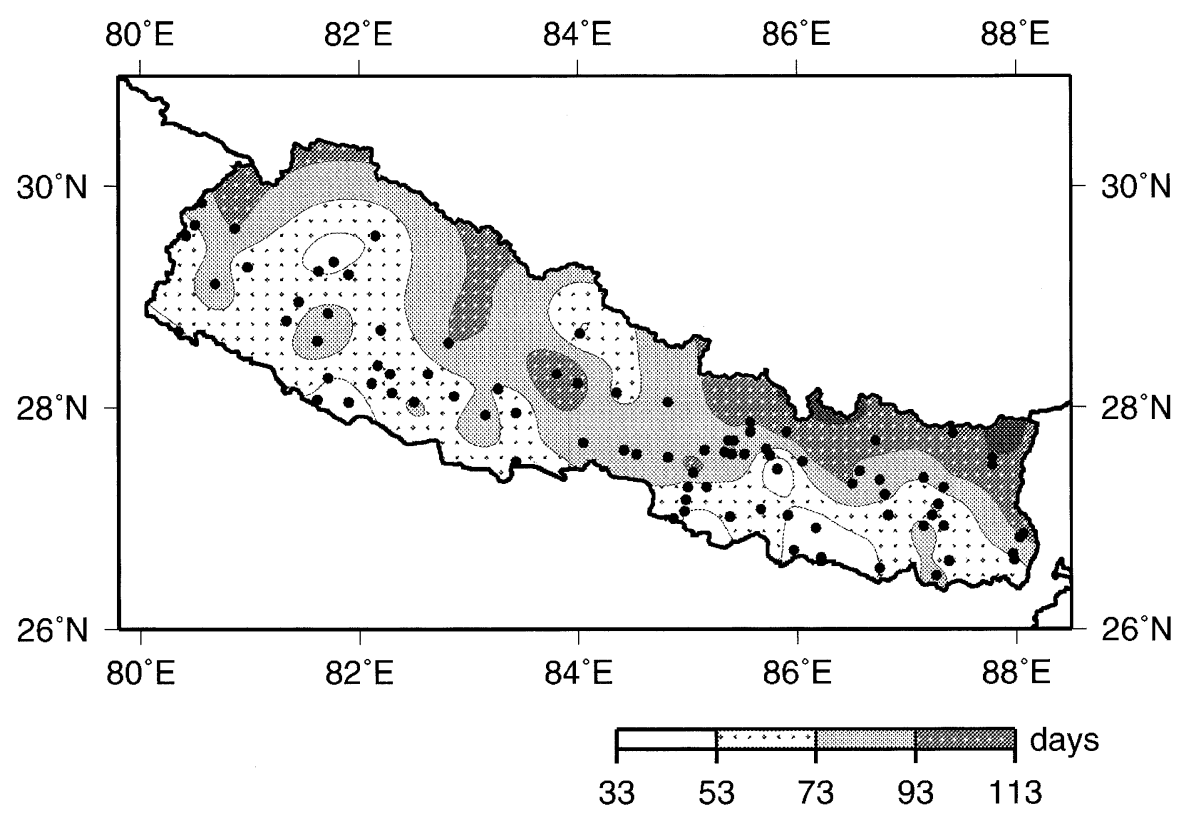

図 4 モンスーン平均雨日数.

雨日数の階級区分は，平均值 73 日を中心に，上下 20 日とし，雨日数の多い地域・少ない地 域を示した。黒丸は使用した雨量観測地点.

Fig. 4 Distribution of average number of rainy days $(\geqq 0.1 \mathrm{~mm} /$ day) during the monsoon. To classify the regions into much rainy day areas and/or less rainy day areas, rainy days are classified at intervals of 20 days from the average value of 73 days in Nepal. Solid circles are the meteorological stations used in the present study.

の年および地点の平均值）は約 $1,410 \mathrm{~mm}$ である。 ネパールでは西部ほど，また山岳地帯の北部ほど 降水量は少なくなるとされている（山田, 1971） が，東部では夕ライ平原より山岳地帯で降水量が 多い（図 3)。また，ネパール中央部のポカラ付近 （図 1 の 2) で最も降水量が多い。0.1 $\mathrm{mm}$ 以上 の降雨日数は, 全地点平均で, 観測日 122 日中約 73.3 日で, 主に東部の山岳部で雨日数が多くなっ ている(図 4)。

\section{2）モンスーン降水量・雨日数の経年変化}

ネパール 87 地点におけるモンスーン季の合計 降水量 (図 5-a) と合計雨日数 (図 5-b) の経年変 動をみると, 標準偏差以上を示す降水量の多い年 は 1984, 1985, 1996 年, 少ない年は 1977, 1979, 1992 年であり, 雨日数の多い年は 1978,1980 , 1984,1985 年で少ない年は 1979,1992 年であっ た。降水量の多少と雨日数の多少は同調する傾向
にあるが，量（規模）的には必ずしも一致してい ない。雨者が共に多い多雨年は 1984，1985 年で, 両者が共に少ない少雨年は $1979 ， 1992$ 年となる。 一方, 上記と同様に標準偏差を指標に, 降水量 と雨日数から, 各地点の多雨年・少雨年を決定し, 年ごとの地点数の推移をみたのが図 6 である。図 6 からは，1978，1984，1985 年が多雨年であり， 1977，1979，1992 年が少雨年であるとみなされ る。1977 年 (少雨), 1978 年 (多雨) を除くと, 全地点の合計降水量および合計雨日数から判断さ れる多雨年, 少雨年と一致するが, 両者が完全に 一致していないという事実は降水状況が地域に よって大きく異なることを示唆している。

図 7 は雨日数偏差と降水量偏差に㧍ける各地点 の散布図である。図 7 に基づき, 全地点における 平均値を基準として, 各地点を雨日数・降水量の 偏差が共にプラス, 共にマイナスの地点, 雨日数 

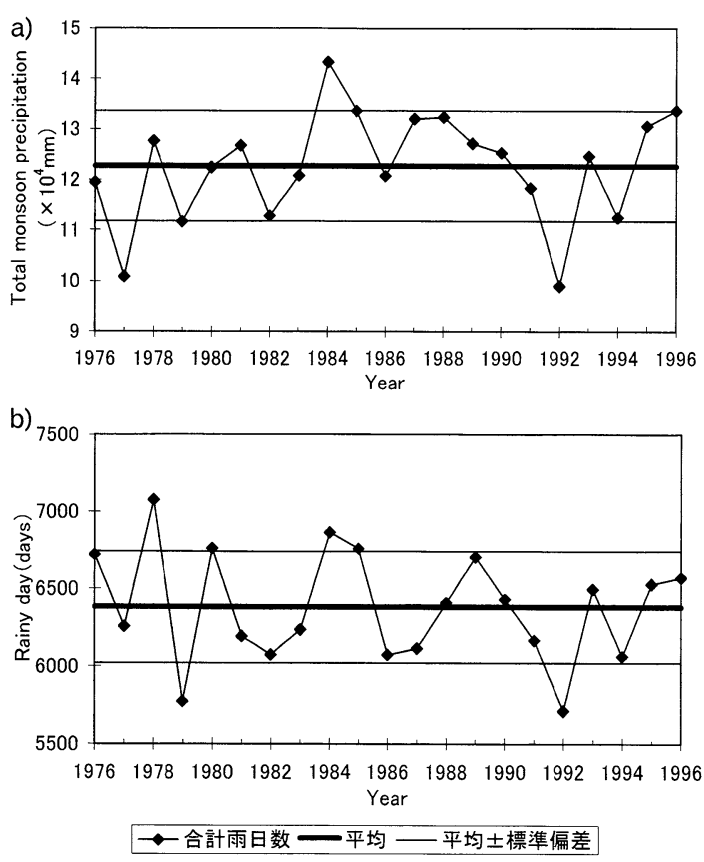

図 5 （a）モンスーン合計降水量の経年変動と, （b）モンスーン合計雨日数の経年変動.

Fig. 5 (a) Interannual variability of the total monsoon rainfall (June to September) for 87 stations in Nepal. (b) Interannual variability of the total number of rainy days during the monsoon (June to September) for 87 stations in Nepal.

が少ないが降水量が多い地点, 雨日数が多いが降 水量が少ない地点の 4 つのカテゴリーに分類した。 分類された観測地点の分布に基づく（図 8）と, ネパールは 6 つの地域, すなわち, 西部地域, 中 央部多雨地域, ヒマラヤ山岳多雨地域, 東部山間 少雨地域, 夕ライ平原少雨地域, 東部多雨地域に 区分できる（図 8）。西部地域は雨日数が少なく, かつ，降水量も少ない地点が多いが，4つの夕イ プ全てが分布している。また, 南東部では同じ少 雨地域でも, 山間部では雨日数が比較的多いのに 対し，タライ平原では雨日数も少ない。

\section{3）日降水量頻度分布の正規化}

次に, 日降水量の大雨の基準值を設定する（た とえば，日降水量の頻度分布の上位 $5 \%$ 以上）た めに, 各地点における日降水量の頻度分布曲線が
正規分布に近似できるかどうかについて検討して みた。日本の各地点での日降水量については, そ の対数または平方根, あるいは立方根を用いて頻 度分布を描くと，近似的に正規分布に従うことが 古くから知られていて，頻度分布の正規化によく 使われている（菊地原, 1959; 鈴木, 1962 など）。 そこで, $0.1 \mathrm{~mm}$ 以上の降水が観測された日を対 象に, 日降水量を対数, 平方根, 立方根に変換し, それらの頻度分布の歪度, 尖度を計算した。歪度 は分布の型の対称性を示す量で，0に近いほど左 右対称を示す。また尖度は分布の型のとがり具合 を示し，3に近いほど正規分布となる。3 種の降 水量変換のうち, 最も正規分布に近い歪度と尖度 を示す降水量変換を採用し，これらの歪度と尖度 を用いて正規性の検定を行った。その結果，変換 された降水量分布が正規分布に従っている地点は 87 地点中 5 地点のみであった。それゆえ, ネパー ルでは, 各地点の日降水量の頻度分布は, 対数, 平方根, 立方根変換では正規化させることが困難 である。

\section{4）確率雨量の算出}

上記のように，ネパールの降水については，頻 度分布の正規化によって大雨の評価を行うことが 困難であることがわかった。一方，降水量の評価 を行う手法のひとつに，確率雨量と再現期間を基 準にする方法がある。これは，ある地点で $X \mathrm{~mm}$ 以上の雨が平均して $T$ 年に一度の割合で起こると 期待されるとき， $X \mathrm{~mm}$ を $T$ 年に対する確率雨量 (降水量の再現期待值) と呼び， $T$ 年を降水量 $X \mathrm{~mm}$ の再現期間と呼ぶものである。標本（観測 値）から直接計算した再現期間を経験的再現期間 と呼ぶが，考え方は以下のようになる。

ある地点の日降水量の観測值が $N$ 年間分与えら れたとき，これを最大から順に並べ，その $j$ 番目 の值を $X_{j}$ とする $(j=1,2,3, \cdots)$ 。 $X_{j}\left(\right.$ 上位 $X_{j}$ まで）の降水は $N$ 年間に $j$ 回起こったことになり， 平均すれば何年に 1 回の割合で起こるのかを求め ることができる。この経験的再現期間の計算法は いろいろあるが，気象庁統計課では信頼限界の計 算から Hazen の式

$$
T_{r}\left(X_{j}\right)=N /(j-0.5)
$$




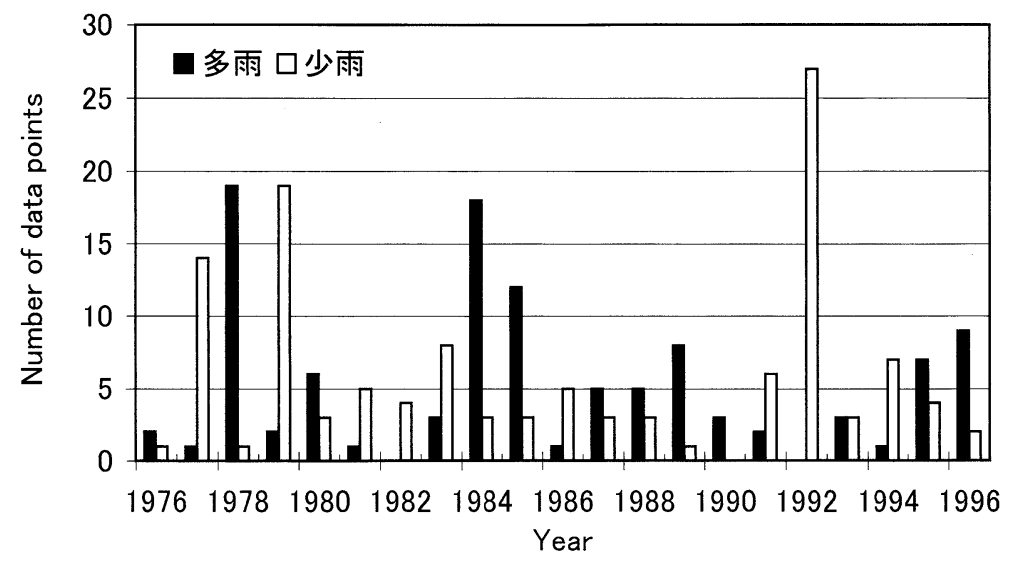

図 6 多雨・少雨地点数の経年変動.

Fig. 6 Interannual variability of the total number of the wet or dry points for 87 stations in Nepal.

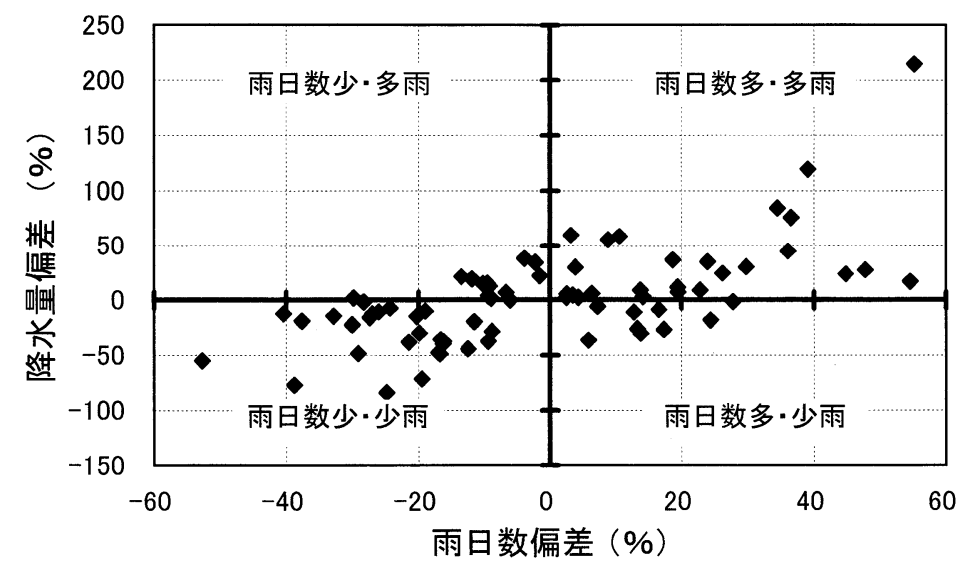

図 7 モンスーン降水量と雨日数偏差の散布.

降水量偏差の 0 值は平均降水量 $1,410 \mathrm{~mm}$ に対応し, 雨日数偏差の 0 值 は平均雨日数 73 日に対応する.

Fig. 7 Relationship between total rainfall and number of rainy days during the monsoon.

Standards of deviations of rainfall and rainy days respectively correspond to $1,410 \mathrm{~mm}$ and 73 days, which are averages in Nepal.

を推奨した（気象庁統計課, 1958)。 $T_{r}\left(X_{j}\right)$ が日 降水量 $X_{j}$ の再現期間である。しかし, $j$ が小さい 時はごく概略の值を示すにすぎず，「統計期間を超 える大きな再現期間の推定を行うのは本質的に極 めて危険である」と考えられている（気象庁統計 課, 1958)。日本各地における再現期間について
は，菊地原（1959）が各気象官署の観測值から経 験的再現期間曲線を求めて 6 つの型に分類し, 菊 地原（1975）で詳細に結果を発表している。また, 確率雨量の推定は災害対策のための設計基準に必 要であるため, 耐用期間と安全率に基づいた再現 期間から確率雨量を推定する研究（正務, 1967) 


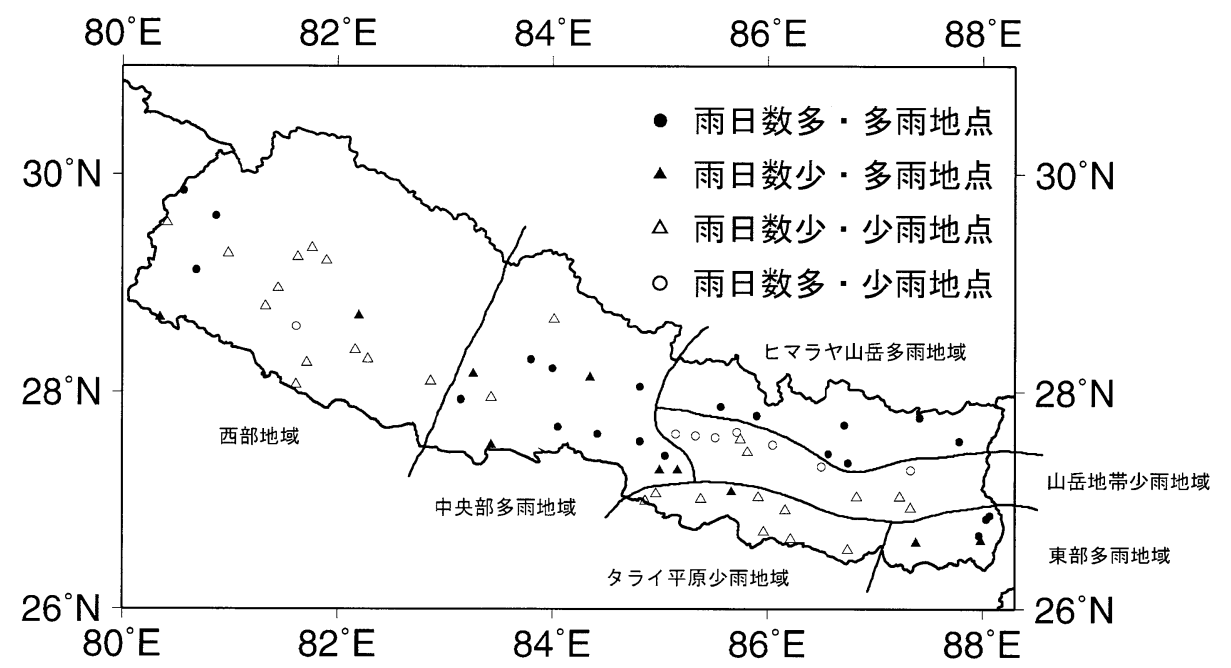

四 8 モンスーン降水量と雨日数に基づいたネパールの地域区分.

Fig. 8 Regional divisions of Nepal based on the relationship between total rainfall and number of rainy day during the monsoon shown in Fig. 7.

などが行われている。

本研究ではまず, Ohmori and Hirano（1988） が規模一頻度分布の関係の解析に用いている手法 を参考にして, 地点ごとに, 降水量規模（日降水 量のパラメーター）とその累積頻度の関係を求め, 降水量規模ごとの再現期間を算出した。この手法 は, 日降水量パラメーターとその頻度分布の関係 を負の指数分布 (ガンマ分布) に近似し，その回 㷌式から求められる日降水量一累積頻度関係から, 日降水量の頻度分布上での位置（当該日降水量の 発生確率）を評価するものである。すなわち，日 降水量 $X$ のパラメーターを $x$ とすると, 累積頻度 $F(x)$ は,

$$
F(x)=a 10^{-b x}
$$

と表わされる。また, 日降水量の発生確率 $p(x)$ は,

$$
p(x)=F(x) / F(0)=F(x) / a=10^{-b x}
$$

で求められる。 $x$ は, 対数変換の場合は $x=\log X$, 平方根変換の場合は $x=X^{1 / 2}$, 立方根変換の場合は $x=X^{1 / 3}$ で与えられ, $a, b$ は定数である。回帰式の 係数 $a, b$ は観測地点の特性值で, $a$ は観測地点に おける降水日数の多寡を反映し, $b$ は日降水量の 増加に対する降水日数の減少率を表わす。観測值 に基づく式（2）の回帰式から，その地点における
普遍性をもった累積頻度 $F(x)$ が求められる。

日降水量の再現期間 $r_{x}$ は,

$$
r_{x}=(1 / p(x)) / N=10^{b x} / N
$$

同時に, 再現期間 $r_{x}$ の確率雨量 $x$ は,

$$
x=\left(\log \left(N \cdot r_{x}\right)\right) / b
$$

で与えられる。但し， $N$ は観測年数である。この 手法を用いることにより，任意の日降水量の再現 期間を求めることができ，また，任意の再現期間 を持った確率雨量を算出できる。1 年のある期間 を対象とした場合は，「その期間（本研究の場合， モンスーン季) の降水に関する再現期間および確 率雨量」ということになる。

なお, 確率雨量の推測については, 「現在, 降雨 量頻度分布の理論的根拠が明確でないため, 推測 結果と資料の経験的分布との適合度を検定し, 最 もよく適合する結果の得られる方法を採用する」 というのがほぼ定説になっている（桑原, 1971)。 さらに桑原（1971）は「資料の選定範囲などによ り，資料の均質化を図った特定值以上の全資料の 頻度分布は，指数分布とみなすことができる」と 述べ，奥田（1982）は「日降水量 $\geqq 0.1 \mathrm{~mm}$ の雨 量階級別度数は指数分布を示す」と述べている。

そこで，ネパールの各地点で，モンスーン期間 


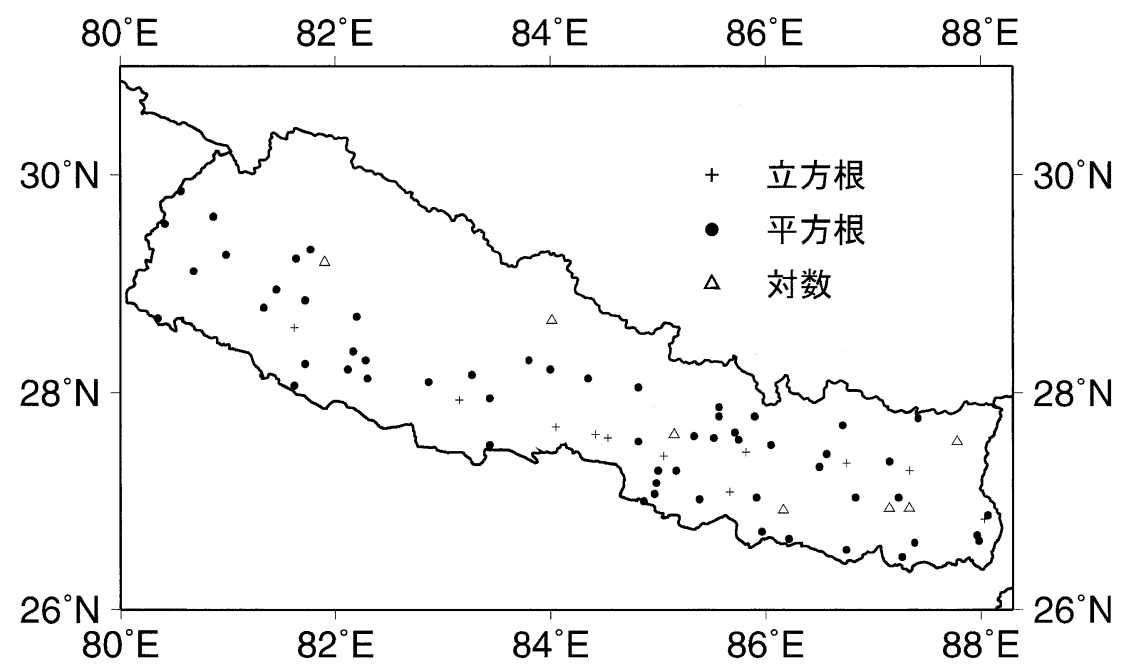

図 $9 \chi^{2}$ 適合度検定合格地点および日降水量変換関数形の分布.

Fig. 9 Meteorological stations selected on the basis of $\chi^{2}$ test for fitness, and the types of conversion of measurement unit of daily rainfall.

中の日降水量 $20 \mathrm{~mm}$ 以上の日を対象に, 降水量 $20 \mathrm{~mm}$ ごとの頻度分布を作成した。そして上位 （降水量の多い方）からの累積頻度を求め, 日降水 量を対数, 平方根, 立方根に変換し, 地点ごとに 式（2）の回帰式を求めた。3 種の降水量変換を用 いた回帰式の内, 最も適合の良い回帰式を求める ために, 決定係数（相関係数の二乗）の值が最大 になる降水量変換を採用した。さらに，近似でき ているかを $\chi^{2}$ 適合度検定で検証し，適合した 75 地点（図 9）について, 各規模の日降水量が観測 される再現期間 (理論值) を算出し, 確率雨量を 求めた。図 9 には各地点の確率雨量を求めるのに 使用した降水量変換の種別をも示したが，ネパー ルの日降水量は主に平方根に変換することで指数 分布に最もよく近似できた。

図 10 には 75 地点の 5 年確率雨量の分布を示し た。 5 年確率雨量はおおむねヒマラヤに沿うよう に東西に帯状に分布し，かつ，南に向かって大き くなる。念のため, Hazenの式（1）を用いて各 地点の経験 5 年確率雨量を計算してみたところ, 理論的 5 年確率雨量分布（図 10）と同じような結 果になったので, 今回の計算結果については問題 ないと思われる。

\section{5）大雨発生年・地域の把握}

ネパールの降水量を正規化させることが困難で あること, 抢よび, 確率雨量の適合度検定では, 最も適合が悪い地点でも日降水量が $160 \mathrm{~mm}$ 以上, 再現期間が 3 年以上であれば統計的に有意である ことがわかったので, 本研究では 5 年確率雨量以 上の降水が観測された日を大雨発生日と定義した。

この定義に基づき, 図 9 に示したネパール全域 の 75 地点について, 地点ごとに大雨発生日数を調 べ, 合計数の年々変動をみてみた（図 11）。標準 偏差を基準にすると，1981，1987 年には大雨が 多発し，1977，1992 年には少ない。大雨として 降った全雨量を合計した雨量の年々変動（図 12） でも，1981，1987 年は多く，1977，1992 年は少 ない。さらに，どこで大雨が降っているかをみる ために, 大雨発生日数を, 先に区分した 6 つの地 域ごとに分けて調べた（図 13）。眓 13 によると, 1981 年には, 西部地域と中央部多雨地域で大雨 が多発しており, 東部山間少雨地域でも大雨が多 かった。また, 同じょうに大雨発生日数が多かっ た 1987 年には, 夕ライ平原少雨地域で大雨が頻発 し, 東部山間少雨地域と東部多雨地域でも大雨が 多かった。 


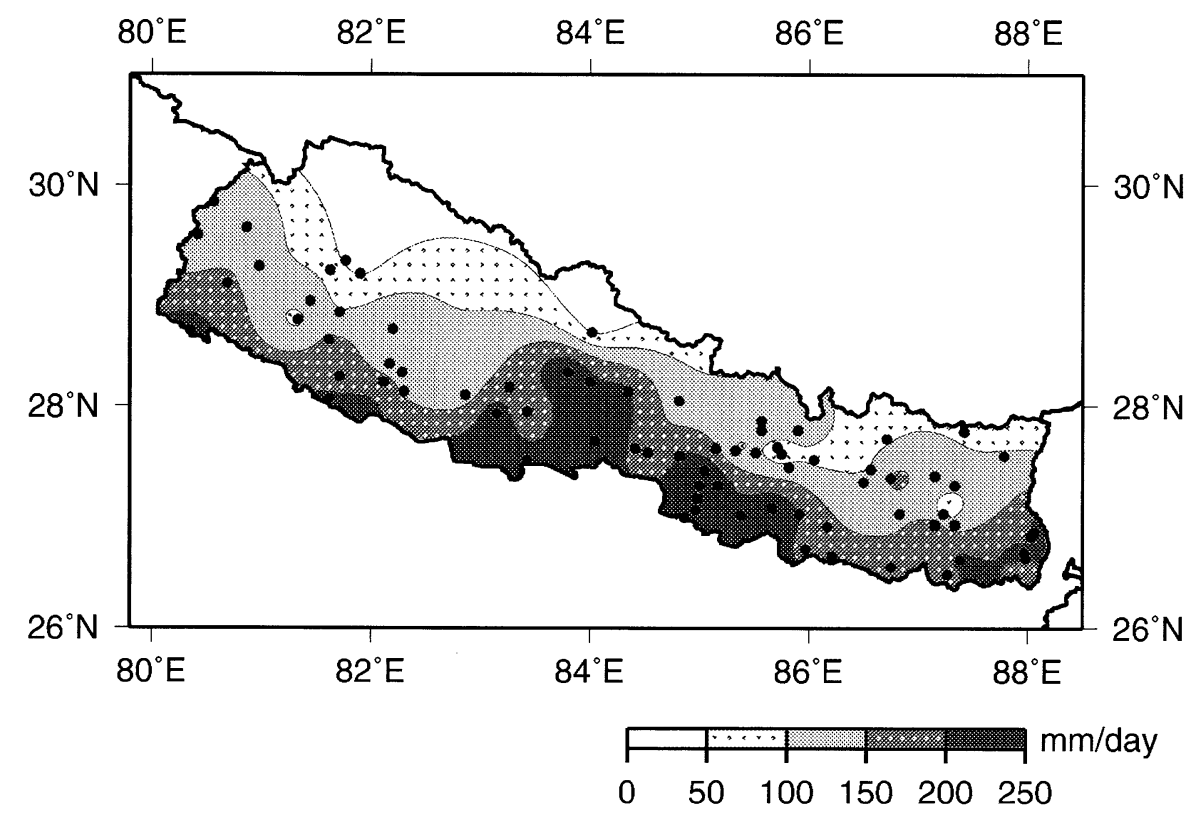

図 105 年確率雨量の分布.

Fig. 10 Distribution of 5-year probable rainfall calculated from frequency distribution of daily rainfall.

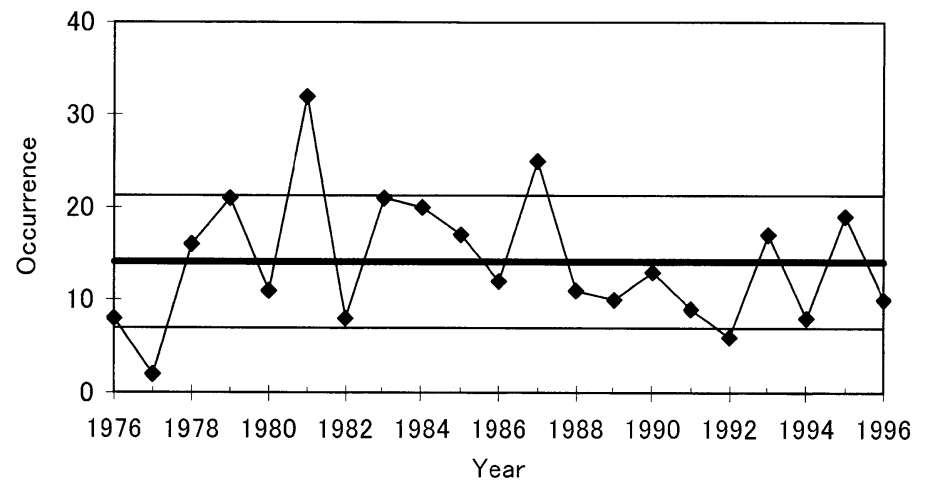

$\multimap$ 発生回数 一一平均 一一平均士標準偏差

図 11 大雨発生日の延べ日数の経年変動.

Fig. 11 Interannual variability of the number of heavy rainy days, which is expressed by 5 -year probable rainfall or over among 75 stations in Nepal each year. 


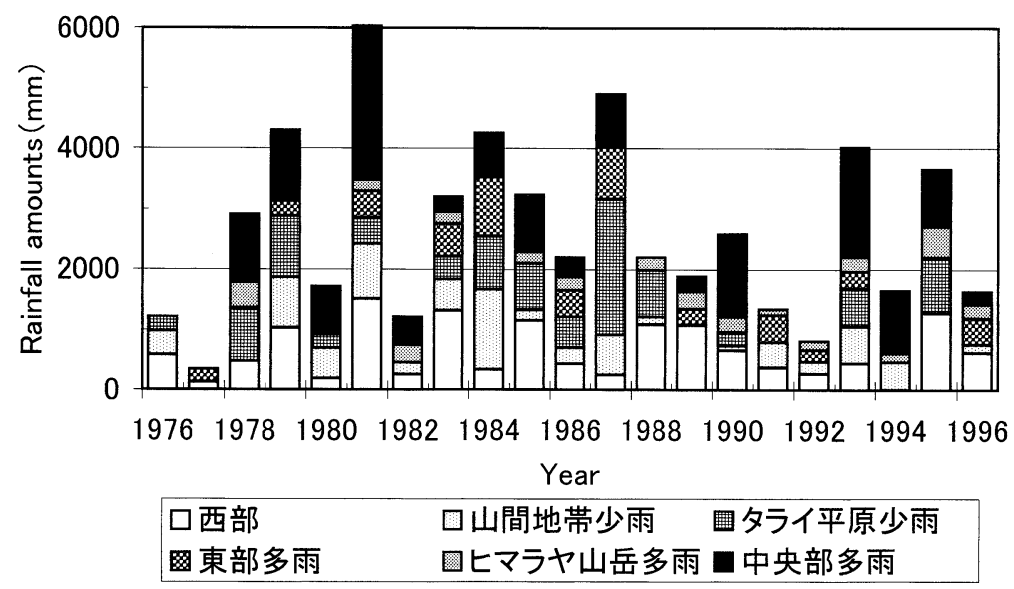

図 12 ネパールにおける 6 つの地域別大雨合計雨量の経年変動.

Fig. 12 Interannual variability of total heavy rainfall, which is expressed by total rainfall for 75 stations with 5 -year probable rainfall or over among 6 regions in Nepal each year.

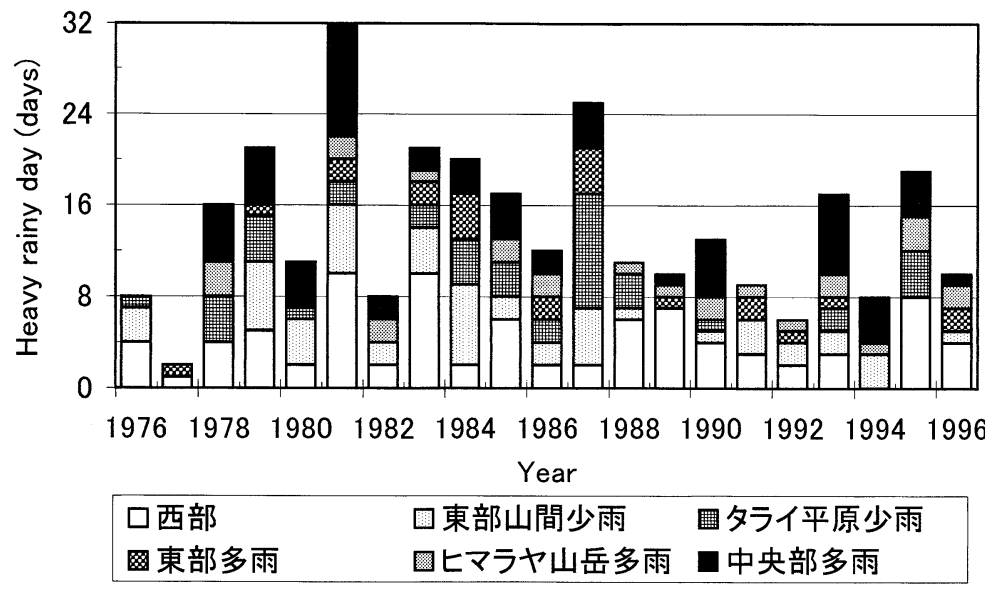

図 13 ネパールにおける 6 つの地域別大雨発生日数の経年変動.

Fig. 13 Interannual variability of total number of heavy rainy days, which is expressed by 5 -year probable rainfall or over for 75 stations among 6 regions in Nepal each year. 
表 1 関係各要素の各年別の多寡の比較. $\bigcirc \cdots$ 多い $\times \cdots$ 少ない

Table 1 Comparison of abundance or lack of rainfall for the different parameters of rainfall in individual years from 1976 to 1996.

\begin{tabular}{|c|c|c|c|c|c|c|c|c|c|c|c|c|c|c|c|c|c|c|c|c|c|}
\hline 年 & 76 & 77 & 78 & 79 & 80 & 81 & 82 & 83 & 84 & 85 & 86 & 87 & 88 & 89 & 90 & 91 & 92 & 93 & 94 & 95 & 96 \\
\hline モンスーン降水量 & & $\times$ & & $\times$ & & & & & $\bigcirc$ & $\bigcirc$ & & & & & & & $x$ & & & & O \\
\hline モンスーン雨日数 & & & $\bigcirc$ & $x$ & 0 & & & & 0 & $\bigcirc$ & & & & & & & $\times$ & & & & \\
\hline 多雨地点数 & & $x$ & $\bigcirc$ & $\times$ & & & & & $\mathrm{O}$ & $\bigcirc$ & & & & & & & $\times$ & & & & \\
\hline 大雨発生回数 & & $\times$ & & & & $\bigcirc$ & & & & & & ○ & & & & & $\times$ & & & & \\
\hline 大雨合計雨量 & & $\times$ & & $\bigcirc$ & & 0 & & & $\bigcirc$ & & & $\bigcirc$ & & & & & $\times$ & & & & \\
\hline
\end{tabular}

\section{IV. 考 察}

これまでの研究では，ネパールのモンスーン 降水量は平均 1,422.8 mm (Shrestha, 2000: 1957 ～ 1988 年 60 地点平均）とされており, 本 研究でもほぼ同じ值 $(1,410 \mathrm{~mm})(1976$ ～ 1996 年 87 地点平均) であった。また Shrestha (2000) では，モンスーン降水量が多い年は 1984 年, 少 ない年は 1977，1982 年であると述べているが， 本研究では 1984，1985，1996 年が多雨， 1977, 1979，1992 年が少雨となる。1984 年 (多雨), 1977 年 (少雨) は一致したが, 1985 年 (多雨), 1979 年 (少雨) は一致しなかった。一方, 本研究 でモンスーン降水量・雨日数・大雨発生回数・大 雨合計雨量ともに少ない年となった 1992 年は, 対 象期間が 1948 ～ 1994 年である Shrestha et al. (2000) の中の「1992 年は最も乾燥した年である」 という記述と一致する。

ネパールのモンスーン降水量・雨日数に基づき, 本研究ではネパールを 6 つの地域に区分した（図 8)。これと 5 年確率雨量分布（図 10）との関係を みると, 中央部多雨地域と東部多雨地域では確率 雨量も同様に大きい。しかし同じ多雨地域でも, ヒマラヤ山岳多雨地域の確率雨量は小さく, 山岳 地域では日単位でみると, 弱い雨が頻繁に降ると 考えられる。また, 夕ライ平原少雨地域の確率雨 量は大きいので, この地域では雨の降る日が少な いにもかかわらず, 強い雨が降る地域であると判 断される。その詳細なメカニズムの解明は今後の 課題である。

確率雨量については, 日本では「標高の法則」
として確率雨量と高さとの間には線形関係があり, 標高が高いほど確率雨量が大きいとされている (早田, 1958)。しかし，ネパールでは北部山岳地 帯ほど確率雨量が小さく, 南部夕ライ平原に向か うにつれて大きくなった。さらに, 確率雨量の分 布パターン（図 10）は図 3 の平均モンスーン降水 量分布パターンと類似して抢らず，降水量と降雨 強度との間には強い関係がないことを示している。

\section{V. まとめと課題}

本研究では, ネパール国内 87 地点の日降水量の デー夕（1976〜 1996 年）を用い, モンスーン季 （6〜9月：122 日）の日降水量の特性を調べた (表 1)。まず，平均モンスーン降水量は約 $1,410 \mathrm{~mm}$, 平均雨日数は約 73.3 日であり, モン スーン降水量・雨日数が共に多い地点が顕著にみ られた多雨年は $1978 ， 1984 ， 1985$ 年，共に少な い地点が顕著にみられた少雨年は 1977,1979 , 1992 年であった。

次に, 各地点をモンスーン降水量の多少・雨日 数の多少で 4 つに分類し, その分布を検討したと ころ, ネパールは 6 つの地域（西部地域・中央部 多雨地域・ヒマラヤ山岳多雨地域・東部山間少雨 地域・タライ平原少雨地域・東部多雨地域）に区 分することができた。

日降水量の頻度分布に基づき 5 年確率雨量を算 出したところ, 北部山岳地帯ほど 5 年確率雨量は 小さく, 南部夕ライ平原に向かって 5 年確率雨量 は大きくなった。そして 5 年確率雨量をネパール における大雨の基準值とし, 大雨発生日数の経年 変化を調べたところ，1981，1987 年に大雨発生 
日数の多いことがわかった。

ネパール国内では雨季・雨季明けに洪水・土砂 災害などの自然災害が毎年発生する。同国では, 1983 年に「自然災害法」が制定され, ようやく災 害デー夕の収集が始まった。第 1 次情報を住民か らの報告に頼っているため, かなりの誤差を含ん でいると考えられているが，この自然災害による 死者は 1993 ～ 1998 年だけで約 2,400 人となって いる。従来，ネパールでは災害を「神のなせる業 (Act of God)」と呼び, 自分達ではどうにもなら ないものとしてあきらめていた。しかし近年の人 口増加, それに伴う農地開発のための森林減少に よって, 集中豪雨による地すべり・崩壊・土石流 などの土砂災害に対する防災が重要であると指摘 されている。今後はデータの蓄積と共にネパール の雨量と災害が発生するプロセスや地域的特徴を 長期的に研究し, その変化を検討する必要があろ う。

\section{謝 辞}

本研究を進めるにあたっては, His Majesty's Government of Nepal Ministry of Science and Technology Department of Hydrology and Meteorology 局 長の Mr. Adarsha P. Pokhrel のご好意により, 多くの デー夕を収集することができました。この莫大なデー夕 の整理をするにあたっては, 当時理学部地学科地理学課 程 4 年の井上知栄さんに手伝って頂きました。以上の 方々にこの場を借りて厚く御礼申し上げます。また，そ の他お世話になった皆様に感謝いたします。

\section{注}

1）データは以下の出版物から入手した.

His Majesty's Government of Nepal, Ministry of Science and Technology, Department of Hydrology and Meteorology (DHM) 2000. Daily Precipitation Records of Bagmati Zone Through 1996. DHM, Kathmandu, 672pp ;

Daily Precipitation Records of Bheri, Rapti \& Dhaulagiri Zone Through 1996. 707pp;

Daily Precipitation Records of Gandaki \& Narayani Zone Through 1996. 585pp;

Daily Precipitation Records of Janakpur \& Sagarmatha Zone Through 1996. 687pp;
Daily Precipitation Records of Koshi \& Mechi Zone Through 1996. 756pp;

Daily Precipitation Records of Lumbini Zone Through 1996. 274pp;

Daily Precipitation Records of Mahakali, Seti \& Karnali Zone Through 1996. 563pp

\section{文献}

菊地原英和 (1959): 確率雨量について（再現期間の計算 法とその問題)。気象研究ノート, 10, 125-139.

菊地原英和 (1975): 全国気象官署における日降水量の再 現期間. 災害の研究，8，64-72.

気象庁統計課 (1958): 日降水量の再現期間の推定法に関 する調查. 測候時報, $\mathbf{2 5}, 181-186$.

桑原英夫 (1971): 水文統計資料としての降雨資料の性格 一日雨量資料について（その 2) 一。農業土木学会誌, 39, $146-159$.

正務 章 (1967): 設計資料として利用しうる降水量の確 率限界值. 水利科学, 10, 25-38.

Nayava, J.L. (1980): Rainfall in Nepal. The Himalayan Review Nepal Geographical Society, $12,1-18$.

Ohmori, H. and Hirano, M. (1988): Magnitude, frequency and geomorphological significance of rocky mud flows, landcreep and the collapse of steep slopes. Zeitschrift für Geomorphologie, Suppl. Bd., 67, 55-65.

奥田 㩟 (1982): 日本に扔ける大雨の地域特性. 災害の 研究, 13, 24-47.

Shrestha, A.B., Wake, C.P., Dibb, J.E. and Mayewski, P.A. (2000): Precipitation fluctuations in the Nepal Himalaya and its vicinity and relationship with some large scale climatological parameter. Intern. J. Climato., 20, 317-327.

Shrestha, M.L. (2000): Interannual variation of summer monsoon rainfall over Nepal and its relation to Southern Oscillation Index. Meteorology and Atmospheric Physics, $75(1 \cdot 2), 21-28$.

鈴木栄一 (1962): 降水量に関する統計的研究 (第 15 報) 一降水量分布則の正規化変換一. 研究時報, 14, 900911.

早田正美 (1958): 佐賀県に扔ける日降水量の Return Period について (第 2 報)。研究時報, 10, 673-679. 山田知充 (1971): ネパールの気候に関する覚え書き. 山岳, 65, 188-198.

Yasunari, T. (1976): Spectral analysis of monsoonal precipitation in the Nepal Himalaya. Seppyo, 42 (Special Issue), 59-65.

安成哲三・藤井理行 (1983): 気象学のプロムナード 15 ヒマラヤの気候と水河一大気圈と雪水圈の相互作用一. 東京堂出版.

(2003 年 9 月 16 日受付, 2004 年 7 月 2 日受理) 